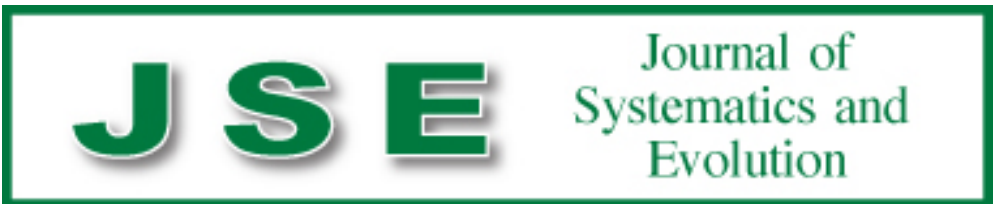

\title{
More than one sweet tabaiba: disentangling the systematics of the succulent dendroid shrub Euphorbia balsamifera
}

This is the accepted version of the following article:

Riina, R., Villaverde, T., Rincón-Barrado, M., Molero, J. and Sanmartín, I., More than one sweet tabaiba: disentangling the systematics of the succulent dendroid shrub Euphorbia balsamifera. Journal of Systematics and Evolution.

which has been published in final form at [https://doi.org/10.1111/jse. 12656]. This article may be used for non-commercial purposes in accordance with the Wiley Self-Archiving Policy [http:// www.wileyauthors.com/self-archiving].

\begin{tabular}{|c|c|}
\hline Abstract: & $\begin{array}{l}\text { The sweet tabaiba (Euphorbia balsamifera Ait.) is one of the classical } \\
\text { examples of the disjunct biogeographic pattern known as Rand Flora. } \\
\text { This species is currently circumscribed to comprise two subspecies, } \\
\text { Euphorbia balsamifera subsp. balsamifera and E. balsamifera subsp. } \\
\text { adenensis (Deflers) P.R.O. Bally, with their respective areas of } \\
\text { distribution separated by a gap of about } 2000 \mathrm{~km} \text { across central-east } \\
\text { Africa. We use multiple sources of evidence including phylogenomics, } \\
\text { morphometrics, lineage ages, and climatic niche analysis to disentangle } \\
\text { the confusing taxonomy around this charismatic Euphorbia lineage. } \\
\text { Based on our integrative approach, we reestablish the two current } \\
\text { subspecies to the rank of species (E. balsamifera Ait., E. adenensis } \\
\text { Deflers) and resurrect the long forgotten E. sepium N.E. Br., a commonly } \\
\text { used species in the western Sub-Saharan and Sahelian regions. The } \\
\text { taxonomic treatment presented here includes an identification key, } \\
\text { updated morphological descriptions, and lectotypification of several } \\
\text { names. }\end{array}$ \\
\hline
\end{tabular}




\section{More than one sweet tabaiba: disentangling the systematics of the succulent dendroid shrub Euphorbia balsamifera}

Short Title: More than one sweet tabaiba (Euphorbia)

Ricarda Riina1*, Tamara Villaverdeㄹ, Mario Rincón-Barradoㄹ, Julià Molero², and Isabel Sanmartín ${ }^{1}$

${ }^{1}$ Real Jardín Botánico (RJB-CSIC), Plaza de Murillo 2, 28014 Madrid, Spain

2Departament de Biologia, Sanitat i Medi Ambient, Facultat de Farmàcia (GReB-IRBio), Universitat de Barcelona, 08028 Barcelona, Spain

*Author for correspondence. Ricarda Riina, E-mail: rriinalrjb.csic.es, Tel: +34 914203017

Abstract The sweet tabaiba (Euphorbia balsamifera Ait.) is one of the classical examples of the disjunct biogeographic pattern known as Rand Flora. This species is currently circumscribed to comprise two subspecies, Euphorbia balsamifera subsp. balsamifera and E. balsamifera subsp. adenensis (Deflers) P.R.O. Bally, with their respective areas of distribution separated by a gap of about $2000 \mathrm{~km}$ across central-east Africa. We use multiple sources of evidence including phylogenomics, morphometrics, lineage ages, and climatic niche analysis to disentangle the confusing taxonomy around this charismatic Euphorbia lineage. Based on our integrative approach, we reestablish the two current subspecies to the rank of species (E. balsamifera Ait., E. adenensis Deflers) and resurrect the long forgotten E. sepium N.E. Br., a commonly used species in the western Sub-Saharan 
and Sahelian regions. The taxonomic treatment presented here includes an identification key, updated morphological descriptions, and lectotypification of several names.

Key words: divergence times, Euphorbia, Euphorbiaceae, Macaronesia, phylogenomics, Rand Flora, Sahara, Sahel, taxonomy

\section{Introduction}

Incomplete or poor taxonomic knowledge can bias our understanding of evolutionary and biogeographic patterns, which in turn can hamper biodiversity conservation and management efforts, especially for endemic taxa and cryptic species (Brito, 2004; Statler et al., 2007). Molecular phylogenetics has greatly contributed to overcome the so called taxonomic impediment (de Carvalho et al., 2005) by improving classification schemes that foster further studies at different taxonomic levels (e.g., Olmstead et al., 2009; van Ee et al., 2011; LPWG 2013; Jiménez-Mejías et al., 2016; Soreng et al., 2017; Xiao \& Simpson 2017). In addition, information from molecular phylogenetics and DNA barcoding (Hubert \& Hanner 2015; Rannala 2015; Lavinia et al., 2017) in combination with other sources of data is being used more and more for species discovery and taxonomic delimitation in different groups (e.g., Smith et al., 2007; Cheek et al., 2016; Alors et al., 2016; Nugnes et al., 2017; Souza et al., 
2017). More recently, the rapid consolidation of high throughput sequencing (HTS) techniques coupled with novel analytical tools is providing massive amounts of sequence data, which can potentially resolve recalcitrant regions of the tree of life (but see Olmstead \& Bedoya, 2019). Phylogenomics (i.e., phylogenetics using genome-scale datasets) can also contribute to clarify long standing taxonomic controversies, and even more in the context of an integrative taxonomic approach (e.g., Prata et al., 2018; Frajman et al., 2019).

While working on the evolution of Rand Flora lineages of Euphorbia (Villaverde et al., 2018), we stumbled upon the taxonomic uncertainty surrounding Euphorbia balsamifera Ait. This species belongs to Euphorbia section Balsamis Webb \& Berthelot, a clade in E. subgenus Athymalus Neck. ex Rchb. (Peirson et al., 2013). The species, as presently circumscribed ( $E$. balsamifera sensu lato), comprises two subspecies: E. balsamifera subsp. balsamifera and E. balsamifera subsp. adenensis (Deflers) P.R.O. Bally (Govaerts et al., 2000; Peirson et al., 2013), which are congruent with two disjunct areas separated by a gap of more than $2000 \mathrm{~km}$ across central Africa (Fig. 1). Euphorbia balsamifera s.l. is popularly known as "tabaiba dulce" (sweet tabaiba) in the Canary Islands, but it has many other common names across its entire geographic 
range. It is a dioecious, pachycaul, succulent dendroid shrub adapted to extreme thermal habitats and growing on rocky to sandy substrates. Pachycaul succulence is a specific condition in which water storage occurs in nonphotosynthetic parenchyma derived from the vascular cambium (Hearn et al., 2013) and represents a quite distinct condition from the great majority of succulent Euphorbia, which involves significant water storage parenchyma in the cortex and a persistent, photosynthetic periderm.

As many species in the genus, Euphorbia balsamifera s.l. has been traditionally used by humans as food (Sahel; latex is boiled and eaten as a gelatine), medicine (Sahel, Western Sahara, Morocco), chewing gum, and cork for wine bottles (Canary Islands). In the African Sahel, the species is propagated from cuttings to build living fences that provide sand stabilization, erosion control, and protection of crops from livestock (Dolbear 2016).

There are other Euphorbia species, distantly related to E. balsamifera, that are also called tabaibas. They belong to E. section Aphyllis, a clade of 23 MacaronesianAfrican dendroid shrubs in a different subgenus-E. subgenus Esula-(Barres et al., 2011, 2017; Riina et al., 2013). The fact that $E$. balsamifera s.l. is the only "sweet" of the tabaibas probably has to do with the apparent lack of bitterness of its latex in comparison 
with tabaiba species in E. section Aphyllis. The milky latex of most Euphorbia species can be toxic, and may cause skin and eye inflammation of different degrees depending on the species (Webster 1986; Eke et al., 2000; Vasas et al., 2012; Otang et al., 2014). The two subspecies of $E$. balsamifera currently accepted correspond to former taxa at the species level, namely $E$. balsamifera Ait. and $E$. adenensis Deflers (Bally 1965). On the other hand, populations of E. balsamifera s.l. from the west-central Africa were recognized in the past under two different names-E. sepium N.E.Br. and E. rogeri N.E.Br.-but they were later reduced to the subspecies level as E. balsamifera subsp. sepium with $E$. rogeri under its synonymy (Maire 1938). Both sepium names are currently considered synonyms of $E$. balsamifera subsp. balsamifera (Govaerts et al., 2000; Peirson et al., 2013). In a study focused on the karyological evolution of Macaronesian dendroid Euphorbia, Molero et al., (2002), in disagreement with Govaerts et al., (2000), recognized three taxa at the rank of subspecies, accepting $E$. balsamifera subsp. sepium along with the other two subspecies. However, Govaerts' view of the group prevailed and was later adopted by Peirson et al., (2013) in their sectional classification of $E$. subgenus Athymalus using a phylogenetic framework. Unfortunately, accessions representing typical localities of $E$. subsp. sepium were 
not sampled in that work, which only included samples of subsp. balsamifera from the Canary Islands, and subsp. adenensis from Oman (Peirson et al., 2013).

In a recent phylogenomic study, Villaverde et al. (2018) used DNA sequences from exons of 296 orthologous low-copy-nuclear loci representing most sections of Euphorbia subgenus Athymalus and a relatively good population sampling across the entire range of Euphorbia balsamifera s.l. to analyse phylogenetic relationships within this enigmatic species. They recovered three wellsupported clades, which were tentatively labeled in their paper as E. balsamifera subsp. adenensis, E. balsamifera subsp. balsamifera, and E. balsamifera subsp. sepium (Villaverde et al., 2018). Here, we use an integrative approach that combines evidence from phylogenomics and lineage divergence times generated by Villaverde et al. (2018) with information from morphology, morphometrics, occurrence data, and climate niche analysis to revise and update the taxonomy of Euphorbia balsamifera.

\section{Materials and Methods}

\subsection{Phylogenomics and divergence times}

Phylogenetic information on the studied taxa and related lineages within Euphorbia subgenus Athymalus, as well as estimates of divergence times, are based on the study of Villaverde et al. (2018). 


\subsection{Species occurrences and morphological study}

Taxon occurrence information was obtained from herbarium specimen labels. When geographic coordinates were not available from collection labels, if possible specimens were georeferenced using Google Maps depending on the locality data recorded. Table S1 in supporting Information includes all specimen records filtered and curated from the original row-set of data downloaded from GBIF (http://doi.org/10.15468/dl.0qiyuu) plus records from other sources (i.e., herbarium collections not available in GBIF). This dataset (Table S1) was used to create the updated distribution map of the studied taxa using the Dismo Package in R (R Core Team 2015; Hijmans et al., 2013)

A comparative morphological study of Euphorbia balsamifera s.l. was conducted using specimens from the following herbaria: $B, B C N, B M, D A K A R, E, F R, F T, G, G M$, K, L, LPA, P, M, MA, MPU, RAB, U, UPS, W, WAG (acronyms follow Index Herbariorum, available at https://sweetgum.nybg.org/science/ih/). In addition, we checked types and other historic collections available online via JSTOR Global Plants and virtual herbarium collections. Lectotypifications were made, when necessary, following the rules of the International Code of Nomenclature for algae, fungi, and plants (Turland et al., $2018)$. 


\subsection{Climatic Niche analysis}

Occurrence data points (see above) of the putative species analysed here are listed in Table S1. We downloaded the 19 bioclimatic variables from the WorldClim dataset website (http://worldclim.org/version2) at 2.5 arc minutes $(\sim 5 \mathrm{~km})$ (Hijmans et al., 2005). To understand the climatic differences among the three species, we performed niche comparison analysis using the ecospat package (Di Cola et al., 2017) in R version 3.4.1 (R Core Team 2017). A PCA was built using the data of the 19 bioclimatic variables within the environmental space, which was defined based on the species distribution ranges (Fig. 1) as follows: E. balsamifera from $W 9.01^{\circ}$ to $W 18.15^{\circ}$ and $N$ $25.9^{\circ}$ to $\mathrm{N} 31.55^{\circ} ;$ E. sepium from $W 17^{\circ}$ to $\mathrm{E} 17.5^{\circ}$ and $\mathrm{N}$ $7.75^{\circ}$ to $\mathrm{N} 26.9^{\circ}$; and $E$. adenensis from $\mathrm{E} 37.06^{\circ}$ to $\mathrm{E}$ $54.8^{\circ}$ and $\mathrm{N} 9.7^{\circ}$ to $\mathrm{N} 19.08^{\circ}$.

The environmental space delimited above was divided into a grid of $100 \times 100$ cells, as in Broennimann et al., (2012). To correct for sampling bias and environmental availability and to ensure that the results were independent of the grid resolution, we measured the frequency of species occurrences for each combination of environmental conditions in each grid cell of the environmental space using a kernel smoother function 
applying the ecospat.grid.clim.dyn function of the ecospat package (Di Cola et al., 2017). We calculated the differences in occurrence densities between pairs of the three taxa (ecospat.niche.overlap function) and used the Schöner's D metric to calculate the degree of overlap (from no overlap to complete overlap, i.e., from 0 to 1 ). To assess the similarity of the three niches (using pairwise comparisons), we performed a test of niche equivalency (Warren et al., 2008, Broennimann et al., 2012) with 100 random permutations of occurrences between the two species in the comparison (ecospat.niche.equivalency.test function). To evaluate whether two niches were more or less similar than expected by chance, we performed a similarity test through 100 random shifts of these niches within the available conditions in each of the species environmental space (ecospat.niche.similarity.test function). In both analyses, we tested for niche conservation and niche divergence (i.e., alternative "greater" and "lower"). Finally, we determined the niche expansion, stability and the niche unfilling (Petitpierre et al., 2012) using the ecospat.niche.dyn.index function.

This niche comparison approach is commonly used in the field of biological invasions to compare the native and the exotic niches of the same species (Guisan et al., 2014). In our case, we borrowed this procedure to compare 
the native niches of two different species (e.g., species $A$ and $B)$, and adapted the concepts applied in that field to our case as follows (species A represents the "exotic range" and species B the "native range"): niche stability is the proportion of the niche of species A overlapping with the niche of species $B$, niche unfilling is the proportion of niche B non-overlapping with niche $\mathrm{A}$, and finally, niche expansion is the proportion of niche A nonoverlapping with niche B.

\subsection{Leaf morphometrics}

To provide a quantitative assessment of the relevance of leaf morphology, a character traditionally used in the taxonomy of Euphorbia balsamifera s.l., the following measurements were performed selecting three leaves per specimen: leaf maximum length, leaf maximum width, length from the leaf base to the point of leaf maximum width, and mucron length. We selected mature leaves from young branches below the fourth internode (from the apex) whenever possible. For each measurement, the average of the three leaves measured was taken to represent a given specimen. We measured 29 specimens of subsp. balsamifera, 29 of subsp. sepium, and 22 of subsp. adenensis (80 specimens in total; see Table s2), aiming to cover the geographic range and morphological variability of the three taxa. The type specimen of $E$. sepium was included in 
the analyses; other types were visually inspected but not included in the analyses due to the poor quality of specimens. Finding suitable specimens of subsp. adenensis was particularly challenging because many specimens were poorly preserved (i.e., leafless specimens or just with a few apical leaves remaining), and also because this taxon is not well represented in herbaria. Differences in leaf size and shape among the three taxa were visualized using boxplots and Principal Component Analysis (PCA) . Statistical analyses on each variable (leaf measures) were performed using univariate (ANOVA) and multiple variance (MANOVA) analyses. All analyses were performed in the $\mathrm{R}$ statistical environment V. 3.6 (R Core Team, 2015).

\section{Results}

\subsection{Phylogenomics and lineage ages}

The phylogenetic tree, based on 296 nuclear exon loci and a relatively dense population sampling (110 individuals) covering the vast geographic range of Euphorbia balsamifera s.l. (Villaverde et al., 2018), recovered three highly supported clades (Fig. 2) recognized here at the species level as E. adenensis, E. balsamifera s.s., and E. sepium (see Taxonomic treatment below). Euphorbia sepium was recovered sister to the clade of E. adenensis-E. balsamifera. Age estimates differ among the three lineages, with $E$. sepium diverging at 
approximately $11 \mathrm{Ma}$ (stem age) in the late Miocene and with a crown age of $\sim 7 \mathrm{Ma}$. Divergence between $E$. adenensis and E. balsamifera dates back to the early Pliocene ( 5 Ma), with crown ages of $\sim 4$ and $\sim 3 \mathrm{Ma}$, respectively (Fig. 2).

\subsection{Updating species geographic ranges}

The distribution ranges of the studied species do not overlap (Fig. 1): E. balsamifera s.s. occurs in Macaronesia (all islands in the Canary Archipelago) and in several sparse and isolated patches along the SW coast of Morocco and $\mathrm{N}$ coast of Western Sahara, reaching its southernmost distribution around 26 latitude $\mathrm{N}, 30 \mathrm{~km}$ south of Boujdour (Western Sahara). The more continental of the three species, E. sepium, occurs in western subSaharan Africa and western Sahel, with collection records in Western Sahara, Mauritania, Senegal, Mali, Burkina Faso, Benin, Togo, Nigeria, and W Niger. The most northwestern known populations of $E$. sepium in northern Western Sahara are separated by ca. $190 \mathrm{~km}$ from the $E$. balsamifera s.s. localities along the African Atlantic coast. Finally, the geographic range of E. adenensis, separated from the easternmost localities of $E$. sepium (W Niger) by more than $2000 \mathrm{~km}$, spans from the coast of $\mathrm{E}$ Africa to the southern Arabian Peninsula, with collection records from the $\mathrm{NE}$ coast of Sudan (two records), N 
Somalia, SW corner of Saudi Arabia, Yemen, and Oman, and the island of Abd al Kuri in the Socotra Archipelago. All the herbarium specimens used to update the geographic distribution of the three species (Fig. 1) are listed in the taxonomic treatment below and in supporting Information Table S1.

\subsection{Climatic niche assessment}

Our results indicate a low overlapping of climatic niches among the three species (Schöner's D $<0.30$, Table 1, Fig. 3). The lowest overlapping niche values are among E. sepium and the other two species $(D<0.10$, Table 1$)$. Also, the results of the equivalency test comparing $E$. sepium and E. balsamifera niches showed that the overlapping is significantly smaller than the null distribution (Table 2). The similarity test did not indicate any difference from a random model between $E$. sepium and each of the other two species (Table 2). Niche overlap between Euphorbia balsamifera and E. adenensis is also low (Schöner's D $=0.27$; Table 1), while the equivalency test indicated that these species do not share the same climatic conditions (Table 2). Nevertheless, the similarity test indicated that there are significant similarities between the two niches (p-values $<0.05 ;$ Table 2). Besides, E. balsamifera and E. sepium niches have almost no overlap ( $D=0.004$; Table 1 ) and are 
less close to each other than expected in a random model (equivalency test p-value $=0.009 ;$ Table 2). The $E$. adenensis niche is more similar than expected in a random model to the $E$. balsamifera niche (p-value $=0.019 ;$ Table 2). In sum, the similarity and equivalency tests indicated that the niches of $E$. adenensis and $E$. balsamifera are not significantly equivalent, neither significantly similar nor equivalent to the E. sepium niche.

The values of niche expansion, niche unfilling and niche stability are summarized in Table 3 and visualized in Figure 3. The niches of E. balsamifera and $E$. adenensis show the highest values of niche stability or overlap $(\sigma=$ 0.88 and 0.99; Table 3, Fig. 3), and they also exhibit the lowest values of niche expansion and unfilling (0 and 0.12; Table 3, Fig. 3). The niche stability (overlap) between $E$. sepium and $E$. adenensis is twice as high $(\sigma=$ $0.74)$ as the overlap with $E$. balsamifera $(\sigma=0.36)$ (Table 3, Fig. 3). Finally, the highest values of niche expansion $(\varepsilon=0.63)$ were found between $E$. sepium and $E$. balsamifera, while the highest niche unfilling value $(u=0.64)$ was reported in comparisons between $E$. balsamifera and $E$. sepium (Table 3, Fig. 3).

In the PCA analysis of all climatic variables associated to occurrences of the three putative species (Fig. 4), Euphorbia sepium appears segregated from the 
other two species along the first axis (PC1), which was correlated with temperature-related bioclimatic variables, such as annual mean temperature (biol) and mean temperature of coldest quarter (biol1, Table S2 and Fig. 4), indicating that $E$. sepium is more tolerant to higher temperatures than $E$. balsamifera and $E$. adenensis. In contrast, E. sepium shows a high variation (variance) along the second axis, PC2, which is mainly associated with precipitation variables (annual precipitation, bio12) and temperature seasonality (bio4). Euphorbia adenensis and E. balsamifera shows a lesser degree of segregation (i.e., they exhibit similar climatic tolerances), especially along PC2. The two species, however, appear slightly segregated along $\mathrm{PC} 1$, with $E$. adenensis showing tolerance to higher temperatures than in $E$. balsamifera (Fig. 4)

\section{4 Leaf Morphometrics}

Leaf length, mucron, and leaf shape (assessed as the ratio between maximum length and maximum width) differ significantly between the three taxa, but Euphorbia sepium shows the largest difference for all the measured variables (Fig. 5A, 5C-E, Table 4). Only maximum leaf width is not significantly different (Table 4), with the box-plots of the three species showing a broad overlap for this variable (Fig. 5B). 
In the PCA, the first two components (PC1, PC2)

account for approximately $62 \%$ and $27 \%$ of the observed variance, respectively. Characters contributing significantly to the first component axis PCl were leaf maximum length, leaf length from base to widest part, and mucron length, whereas leaf width is the variable contributing the most (94\%) to the second axis PC2. The scatter plot shows a clear separation between E. adenensis and E. sepium along PC1, but E. balsamifera fills the gap between the two species and partially overlaps with both of them, especially with $E$. sepium. PC2 shows significant overlapping among the three species (Fig. 5F).

\section{Discussion}

Phylogenetic trees are important when addressing biological questions in an evolutionary context, but they are also essential to refine taxonomic knowledge. We used the most robust phylogenetic tree of Euphorbia section Balsamis built to date (Villaverde et al., 2018), and complemented it with additional sources of evidence to support the reestablishment of three lineages at the rank of species. The newly reinstated taxa (E. adenensis, $E$. balsamifera, and E. sepium) were previously treated under the former E. balsamifera s.l., either as subspecies or under synonymy (see taxonomic treatment). 
Our approach is consistent with studies arguing against establishing species limits based solely on genomic data (e.g., Solís-Lemus et al., 2015; Sukumaran \& Knowles 2017). Similar integrative studies have been successful resolving the taxonomy of problematic groups at the species level (e.g., Denham et al., 2019; Li et al., 2019; Perkins 2019; Yang et al., 2019), but they are still scarce in plants, and even more those integrating phylogenomics, divergence time estimations, and phylogeography with morphology and climate niche analysis (e.g., Frajman et al., 2019). Generating large amounts of genomic data continues to be expensive and the steps from taxon sampling to tree inference are considerably longer and bioinformatically more demanding than just generating and analyzing a small set of genes. In addition, placing the resulting phylogeny in a morphological and ecological context using quantitative techniques is also timeconsuming and requires expert knowledge on the focal group (Giribet, 2015) .

Based on a previous work (Villaverde et al., 2018), we recovered three distinct clades within Euphorbia balsamifera s.l. Ten individuals of Euphorbia sepium were clustered with strong support as a monophyletic lineage sister to the clade formed by $E$. adenensis and $E$. balsamifera. This nuclear topology (Fig. 2) was also fully congruent with the chloroplast phylogeny (not shown) 
obtained by Villaverde et al., (2018). Each lineage was represented by 10 or more individuals spread across the entire geographic range, which is desirable when addressing species relationships at the species level where incomplete lineage sorting may have an impact on phylogenetic resolution (Naciri \& Linder 2015).

Estimated divergence times for the origin of these three taxa (5 to $11 \mathrm{Ma;} \mathrm{Fig.} \mathrm{2)} \mathrm{provide} \mathrm{further} \mathrm{evidence}$ for considering these lineages at the rank of species. It has been suggested that clade age should not be used as a single criterion (Lücking 2019) for classification at high taxonomic ranks (e.g., families, genera), but it can be considered as another element within an integrative approach at the lowest ranks (e.g., species). However, divergence times can vary greatly across large plant genera like Euphorbia (Horn et al., 2014), going from recent radiations (i.e., species-rich and relatively young groups) to older clades with various degrees of species richness. For example, Frajman \& Schönswetter (2017) dated time divergences within a small clade (6 spp.) of eastern Mediterranean Euphorbia (E. sect. Pithyusa) to the midlate Pleistocene ( $<1.5$ Mya), which contrasts with the much older age of the split between $E$. balsamifera and $E$. adenensis ( 5 Ma; Fig. 2).

The age of divergence between the disjunct $E$. balsamifera and $E$. adenensis, on each side of Africa, 
agrees well with results from Pokorny et al. (2015; 3.8 Ma) and coincides with a period of global climate warming, the mid-Pliocene Warm Period (Zachos et al., 2008), and increased aridification in Africa (Senut et al., 2009). Clade age and geographic disjunction are in alignment with the climatic vicariance/extinction hypothesis (Mairal et al., 2017), which posits that species' failure to adapt to the new more xeric environments, in combination with niche conservatism, contributed to the geographic isolation of populations in the eastern and western margins of Africa and led to the generation of the allopatric Rand Flora lineages

The much older split of E. sepium ( 11 Ma) predates the formation of the Sahara Desert ( 8 Ma, Senut et al., 2009). This taxon exhibits a much more widespread and inland distribution, as well as a wider climatic niche than either E. adenensis or E. balsamifera (Fig. 3). Our study places the divergence of $E$. sepium in the late Miocene (Tortonian), a period characterized by lower temperatures and wetter environments (Mairal et al., 2017); it is thus possible that ecological vicariance-the appearance of a hostile environment-is involved also in the origin of this clade.

The climatic niche analysis showed that the three species have different climatic niches, especially $E$. sepium. This species' niche barely overlaps with any of 
the other two species, and equivalency tests showed that the bioclimatic conditions where this species occurs are more different than expected by chance when compared with $E$. balsamifera or $E$. adenensis. However, this difference is greater between E. sepium and E. balsamifera, because their expansion and unfilling values are higher than those of the other two species pairwise comparisons (Table 3, Fig. 3). Differences between E. balsamifera and $E$. adenensis niches are not as remarkable, although niche overlap is comparatively low (Schönen'D $=0.271$; Table 1) and there is low conservation according to the equivalency test (Table 2). However, similarity among these niches is higher than expected for a random comparison, and the stability value is high (Table 3). The niche equivalency test is considered very conservative (Aguirre-Gutiérrez et al., 2015), and even if there is a part of both taxa that dwell in an equivalent niche, this can result in not rejecting the null distribution when their means are different. However, similarity between them may be accepted (Glennon et al., 2014).

The allopatric distribution of the three taxa, particularly the large gap between the sister $E$. balsamifera and $E$. adenensis, also supports the reinstatement of the three lineages as separate species. The enormous distance $(>2000 \mathrm{~km})$ separating these two species makes gene flow between them unlikely. Even if 
they are morphologically very similar and perhaps

potentially able to hybridize, isolation by distance will continue to increase genetic divergence and decrease the possibility of gene flow over time (Sexton et al., 2014). The much larger distribution area of Euphorbia sepium compared with the other two species, could be in part the result of human activities due to the common use of this species across the Sahel for live-fencing to protect crops, avoid soil erosion, and keep livestock out of fields (Dolbear 2016).

We show that morphological data, particularly leaf shape and size (Fig. 4), is useful to distinguish Euphorbia sepium from the other two species. As expected by their closest phylogenetic relationship, the morphological separation between $E$. adenensis and $E$. balsamifera is not that clear-cut. The most useful characters distinguishing these two taxa are leaf shape and plant stature. The length of the style fusion and the density of capsule indumentum have also been used to distinguish these species, but they are not taxonomically as useful (see Taxonomic Treatment). A palynological survey (Perez \& Roca-Salinas 1977) reported differences in pollen size between the two species, larger grains in $E$. balsamifera $(47.3-55 \mu \mathrm{m})$ than in $E$. adenensis $(34.32-40.92$ $\mu m)$, but slight differences in exine ornamentation. As far 
as we know, there are no palynological data available for E. sepium.

The criterion of reciprocal monophyly, along with the relatively old stem ages exhibited by the three taxa, compared to those in other Euphorbia lineages (Horn et al., 2014) and within subgenus Athymalus (Villaverde et al., 2018), would be enough to satisfy the unified species concept proposed by De Queiroz (2007), i.e. species as separately evolving metapopulation lineages. Nevertheless, we have shown here that there is additional evidence, including differences in leaf shape/size and climatic tolerances, to support the establishment of three species of sweet tabaiba.

The integration of phylogenomic data with evidence from morphology, distribution ranges, divergence times, and climatic niches, allows us to settle the long-standing confusing taxonomy around the former Euphorbia balsamifera s.l. Our results are consistent with the recognition of three taxa at the species level: E. adenensis, E. balsamifera, and E. sepium. The reinstatement of the widespread $E$. sepium from synonymy uncovers a highly distinct species, whose divergence predates the formation of the Sahara Desert as well as the split between $E$. adenensis and E. balsamifera.

\section{Taxonomic Treatment}




\subsection{Identification key to the studied species of Euphorbia}

1 Compact dendroid shrubs, adult plants usually $<1 \mathrm{~m}$ tall. Leaves obovate-oblong. Styles fused along the lower half of their length. Capsules glabrous, rarely glabrescent. Distributed in eastern Africa (Somalia, east coast of Sudan) and the southern Arabian Peninsula (Yemen, Oman) and Abd-al-Kuri island (Socotra) ..... E. adenensis

1' Open dendroid shrubs, adult plants usually > $1 \mathrm{~m}$ tall. Leaves lanceolate or linear. Styles fused along the lower quarter or less of their length. Capsules pubescent. Distributed in western Africa and the Canary Islands $\ldots . .2$

2 Stem leaves lanceolate to linear-lanceolate, 14.1$44.9(50) \times 2.9-10(12) \mathrm{mm}$; mucron 0.3-0.6 mm long, when present. Ovary and capsule slightly pubescent, sometimes glabrescent. Widespread in the Canary Islands with a few sparse populations along the coast of southern Morocco and northern Western Sahara.....E. balsamifera

2' Stem leaves linear, (32.2)40.5-77.5(100) x 3.1-7.4 mm; mucron (0.1)1-1.5(2) mm long. Ovary and capsule densely pubescent, never glabrous. Occurring in southern areas of the Sahara desert and across Western Sahel .....E. sepium 


\subsection{Euphorbia adenensis Deflers, Bull. Soc. Bot. France 34: 67.1887 . (Fig. $6 \mathrm{~A}-\mathrm{F})$}

Euphorbia balsamifera subsp. adenensis (Deflers) P.R.O. Bally, Candollea 20: 31, 34. 1965. - Tithymalus adenensis (Deflers) J. Sojak, Cas. Nar. Muz. 140: 170, 1972. Syntypes: Yemen, Aden, Scham-Scham near Semaphore, Goldmore Valley, 7 May 1886, Deflers s.n. (lectotype MPU014213!, designated here; isolectotype MPU014212!); Yemen, presqu'ile d'Aden, vallée de Kiosaf, 8 Mar 1885, Deflers s.n. (MPU014216!).

Compact dendroid shrubs, 0.6-0.9(1.2) m tall, usually dioecious, much branched; upper branches $(0.8) 2-3(6) \mathrm{cm}$ long, succulent. Rhytidome whitish-cream, pearly white. Stem leaves 5.6-33.4 x 2.8-9.4 mm, obovate-oblong; apex obtuse to rounded, sometimes minutely mucronate, mucron 0$0.5 \mathrm{~mm}$ long; subcyathial leaves similar in length but wider than cauline leaves, obovate-spatulate. Cyathia solitary, terminal; involucre broadly cupuliform, 2.6-3.4 x 5.4-7.8 mm; glands 5, green-yellowish, transversally oblong, 0.23-0.42 x 0.14-0.22 mm; ovary smooth, glabrous, rarely glabrescent; styles $1.8-2.5 \mathrm{~mm}$, fused half of their length, 0.9-1.2 $\mathrm{mm}$ from the base, tips bifid, stigmatic lobes 0.2-0.4 mm long. Capsule (5)6.5-8.6(10) x (6)7.69(11) mm, globose, rugulose, glabrous, rarely glabrescent. 
Seeds ecarunculate, $2.9-3.8 \times 2.5-3 \times 2.6-3.2 \mathrm{~mm}$, ovoidsubglobose to globose; hilar zone with an angle of $25-30^{\circ}$.

Distribution and habitat: Euphorbia adenensis occurs in eastern Africa (Somalia, east coast of Sudan), the southern Arabian Peninsula (Yemen, Oman), and Abd-al-Kuri island (Socotra), between 150 and $1900 \mathrm{~m}$ elevation (Fig. 1).

Common names: "mark, scar of blow" (Soqotri) (Miller \& Morris, 2004).

Specimens examined (see Table S1 for additional information): OMAN: J.T. Bent 197 (K); P. Hein \& N. Kilian s.n. (B100430939); R.M. Lawton 1892 (K); J.R. Maconochie 2877 (K); J.R. Maconochie 3011 (K); J.R. Maconochie 3545 (K)；A.G. Miller 2201 (E00445559, K)；A.G. Miller 2350 (E0445557, K)；A.G. Miller 7513 (E00445555, K)；A.G. Miller 7514 (E00445562, K); J.J. Morawetz 325 (K); J.J. Morawetz 346 (MICH); A. Radcliffe-Smith 5173 (K). SAUDI ARABIA: I.S. Collenette 1428 (K); I.S. Collenette 1615 (E00221064); A.K. Nasher H42 (E00221063). SOMALIA: P.R.O. Bally 10360 (G, K 5193)； P.R.O. Bally 10858 (G，K)； P.R.O. Bally 11007 (G, K) ; P.R.O. Bally \& R. Melville 15951 (K); R. Bavazzano \& J. Lavranos S.n. (FT); J.J. Beckett 773 (K); S.B. Boaler 86 (K); S. Carter 940 (K); C.N. Collenette 74 (K); J.B. Gillett \& R.W. Watson 23477 (K); P.E. Glover \& Gilliland 555 (BM); O.J. Hansen \& H. Heemstra 6216 (K); C.F. Hemming 1605 (K); C.F. Hemming 
1973 (FT, K) ; C.F. Hemming \& R.M. Watson 3039 (K); J. Lavranos, S. Carter \& al. 24766 (K); E. Peck E266 (G, K) ; M. Thulin 4242 (K); M. Thulin \& M.A. Warfa 5875 (UPS); M. Thulin \& M.A. Warfa 6097 (UPS). SUDAN: S. Carter 1881 (K); Sahni \& Kaamil 699 (K). YEMEN: S. Birdwood 104 (K); E. Bisset $218(\mathrm{~K})$; L. Boulos \& A.M. Rowaished 17088 (E00445574, K); J.S. Collenette 8955 (K, 60195); Deflers s.n. (MPU014212, MPU014213, MPU014216); K.J. Gordon 592A (E00445561); L. Guarino \& L. Balaidi H68 (E00445563)；P. Hein 314 (B100430940); P. Hein 3560 (B1004330941); P. Hein 6331 (B100430938); P. Hein 6709 (B100430948); P. Hein 6780 (B100430945); P. Hein 6880 (B100430947); P. Hein 7816 (B100430946); P. Hein 4881a (W20160006061); C.F. Hemming 523 (K); K.J.V.A25 (K); K.J.V.A30 (K); N. Kilian 4421 (B100451739); N. Kilian 4538 (B100430943); N. Kilian 5097 (B100430942); N. Kilian 6350 (B100430949); N. Kilian 6394 (B10430944); N. Kilian S.n. (B100430941); J.J. Lavranos 15714 (E00445558); J.J. Lavranos 16012 (E00445556);A.G. Miller 3158 (E00445553, K); A.G. Miller. M8073 (E00445564, K); J. Molero s.n. (BCN44902); J. Molero s.n. (BCN44901); J. Molero s.n. (BCN44900); J. Molero s.n. (BCN44899); Ogilvie-Grant \& Forbes Expedition 75 (E00239518); OgilvieGrant \& Forbes Expedition 89 (E00239517, K) ; A. RadcliffeSmith \& S.J. Henchie 4770 (K); N. Sanadiki 41 (K); N. Sanadiki S.n. (E); N. Sanadiki S.n. (E00445560); G. Schweinfurth 132 (G, K); A.R. Smith \& J. Lavranos 52 (K); 


\begin{abstract}
A.R. Smith \& J. Lavranos 666 (K); M. Thulin, B.-A., Beier \& M.A.Hussein 9585 (UPS); Wakefield Expedition 3 (K); J. Waring 121 (K); D. Wood Y1115 (E00445554).
\end{abstract}

5.3 Euphorbia balsamifera Ait., Hort. Kew. 2: 137.1789. (Fig. 6G-L)

Tithymalus balsamifer (Aiton) Haw., Syn. Pl. Succ. 140. 1812. Type: Canary Islands, Tenerife, 1778, F. Masson s.n. (holotype BM000928081!). = Euphorbia capazii Caball., Trab. Mus. Nac. Ci. Nat., Ser. Bot. No. 30, 25. 1935. Type: Morocco. Ifni, Cabo Non, 12 Jul 1934, A. Caballero s.n. (lectotype MA-01-00074670!, designated here) .

Open dendroid shrubs, (0.2)0.8-1.5(4) m tall, usually dioecious, much branched, erect, sometimes decumbent to prostrate in harsher environments; upper branches 2-10 (15) cm long, succulent. Rhytidome grayish, yellowishochraceous. Stem leaves 14.1-44.9(50) x 2.9-10(12) mm, lanceolate to linear-lanceolate; apex mucronate to apiculate, mucron $0.3-0.6 \mathrm{~mm}$ long. Cyathia solitary, terminal; involucre broadly cupuliform, 2.5-3.5 x 5.2-8 mm; glands 5, green-yellowish or orange, transversally oblong, $0.3-0.5 \times 0.1-0.3 \mathrm{~mm}$; ovary smooth, slightly pubescent; styles $(1.6) 1.9-2.3(2.6) \mathrm{mm}$, fused $(0.2) 0.3-0.5(0.7) \mathrm{mm}$ from the base, tips bifid, stigmatic lobes $0.3-0.5 \mathrm{~mm}$ 
long. Capsule (6)7.5-9(12.5) × (7.4)8.5-11(13.8) mm, smooth, globose, punctuated or minutely rugulose, slightly pubescent. Seeds ecarunculate, $2.9-4.0 \times 2.0-3.25 \times 2.0-$ $3.5 \mathrm{~mm}$, ovoid-subglobose; hilar zone with an angle of 30$45^{\circ}$.

Distribution and habitat: Euphorbia balsamifera is common and usually forms dense populations along the dry coastal areas of all Canary islands, and less common and forming scattered populations along the coast of south Morocco and north Western Sahara, between sea level and 500 m (Marrero et al., 1999; Fig. 1, Table S1).

Common names: "tabaiba dulce", sweet spurge, balsam spurge (Canary Islands) (Marrero et al., 1999); "salane", "afdir" (Morocco) ; "lfernan", "azdira" (Western Sahara).

Specimens examined (see Table S1 for additional

information): MOROCCO: J. Aldasoro, J. Calleja \& J. Molero s.n. (BCN126715, BCN126716); A. Caballero s.n. (MPU); J. Fernández Casas \& J. Molero 13706 (G00403653); Font-Quer s.n. (BCN); J. Gattefossé s.n. (RAB); J. Gattefossé s.n. (RAB); J. Lepymny, Rungi \& Ch. Sauvage 1712 (RAB); R. Maire s.n. (MPU, RAB); R. Maire s.n. (MPU); R. Maire s.n. (MPU); R. Maire S.n. (MPU); Y. Ollivier 39 (MPU); Y. Ollivier s.n. (MPU); Y. Ollivier s.n. (RAB); D. Podlech 40516 (GM, G) ; D. Podlech 48600 (GM, G); R. Riina \& L. Pokorny 1962 (MA); R. Riina \& L. Pokorny 1963 (MA); Ch. Sauvage \& Essiaf 16132 (RAB); F. Schuhwerk 90/300 (M); 
Statfford Allen \& Son S.n. (K). SPAIN: El Hierro: J. Molero \& A. Rovira s.n. (BCN45956, BCN45957); C.J. Pitard s.n. (P); M. Rincón-Barrado \& T. Villaverde 16MRB18 (MA); M. Rincón-Barrado \& T. Villaverde 19MRB18 (MA) .

Fuerteventura. I. Álvarez, J. Calvo \& B. Ríos JC2074 (MA768477-1); X. Espadaler s.n. (BCN45989); F. Hekker s.n. (L-0447505); G. Kunkel 11984 (G)； M. Rincón-Barrado \& T. Villaverde 3MRB18 (MA); M. Rincón-Barrado \& T. Villaverde 10MRB18 (MA); M. Rincón-Barrado \& T. Villaverde 15MRB18 (MA) . Gran Canaria: Ch.H. Andreas 6370 (WAG-1800096); E. Asplund S.n. (G, K) ; J. Bornmüller 2859 (G, P) ; B. Dorsey 3 (MICH); F.N. Hepper 907 (K); E. Hulten S.n. (S); G. Kunkel 15260 (G); A. Marrero \& J. Molero S.n. (BCN45973); A. Marrero, J. Molero \& A. Rovira s.n. (BCN129356); Melbold 11749 (M); J. Molero s.n. (BCN45966, BCN45972, $\mathrm{BCN} 45966, \mathrm{BCN} 45975, \mathrm{BCN} 45992, \mathrm{BCN} 45994, \mathrm{BCN} 45993) ; \mathrm{J}$. Molero \& A. Rovira S.n. (BCN129349, BCN129350, BCN129351, BCN129357, BCN129358, BCN129364, BCN129366, BCN129367); R.P. Murray s.n. (G, BM); W. Punt s.n. (U-1274933); D.O. Wijnands 623 (WAG-1800093). Lanzarote: C. Aedo, L. Medina \& A. Quintanar AQ1762 (MA750338); A. Aldridge s.n. (BM); Ch.H. Andreas 6370 (WAG-1800097); Andreas S.n. (M); J. Klackenberg 940401-5 (S); J. Molero \& A. Rovira s.n. (BCN126721); M. Rincón-Barrado \& T. Villaverde 6MRB18 (MA) La Gomera: A. Herrero AH4358.1 (MA); R. Letouzey S.n. (P) ; L.J.G. Van der Maesen 396 (WAG-0158556); J. 
Molero \& A. Rovira s.n. (BCN126717, BCN126718, BCN129352, BCN129353, BCN129355, BCN129362, BCN129363, BCN129365， BCN22672, BCN22673, BCN22674, BCN45960); J. Molero s.n. (BCN45962, BCN45963， BCN45965， BCN45967， BCN45968， BCN45969, BCN45970, BCN45980, BCN45984, BCN45985, BCN45986, BCN45987, BCN45988, BCN4599); R. P. Murray s.n. (K); R. Riina, J. Molero, P.E. Berry 2030 (MA); n.c. n.d. (FR0194912). La Palma: J. Molero s.n. (BCN45979); T. Villaverde \& E. García-Íñiguez 1 TVH17 (MA). Tenerife: E. Asplund s.n. (G); E. Bourgeau 472 (BM, G, P, K); E. Bourgeau 1510 (G, P) ; E. Bourgeau 1810 (G, P, K, BM); BBB. Bresinsky s.n. (M); O. Burchard 163 (G); A. Carrillo s.n. (BCN39880); B. Cabezudo \& S. Talavera n.d. (COFC-95-1, SEV-28116-1)；C. Cool 467 (L); T.J. Dinn 196 (K)； F. Hekker H254312 (L-0447507); H. Knoche S.n. (MPU, 2 sheets); J.C. Lindeman 7128 (L-3799602); T. Lowe s.n. $(\mathrm{BM})$; N. Lundqvist s.n. (UPS); P. Martínez n.d. (COA); J. Molero s.n. (BCN126720, BCN37836, BCN45959, BCN45961, BCN45962, BCN45967, BCN45968, BCN45984, BCN45985, BCN45986, BCN45991, BCN48883); J. Molero \& G. de la Fuente s.n. (BCN45983); J. Molero \& A. Rovira s.n. (BCN37827, BCN37828, BCN45970, BCN126719, BCN129354); C.J. Pitard 353 (L, P, WAG); C.J. Pitard 354 (L, P, WAG); C.J. Pitard 6570 (L); R. Riina et al., 2015 (MA); P. Rodrigo n.d. (COA26937-1); Rolf\& Berg n.d. (O-2003110, O-2003111, O2003109); E.R. Sventenius s.n. (ORT14065, ORT14107, 
ORT14110); E. Valdés-Bermej 5025EV (MA-250333-1); J.H. Vredebregt 324 (WAG-1800092). WESTERN SAHARA: Alferez Feliu s.n. (RAB); J. Caujapé \& A. Marrero s.n. (LPA, MA); R. Maire 2461 (MPU); A. Marrero \& J. Caujapé s.n. (LPA); R. Maire 2536 (MPU); R. Riina \& L. Pokorny 1966 (MA); R. Riina \& L. Pokorny 1967 (MA); R. Riina \& L. Pokorny 1968 (MA) .

5.4 Euphorbia sepium N.E. Br., Fl. Trop. Afr. 6(1): 551. 1911. (Fig. 6M-Q)

Euphorbia balsamifera subsp. sepium (N.E.Br.) Maire in Bull. Soc. Hist. Nat. Afr. Nord 29(26): 450. 1938. Syntypes: Senegal, Sor Island, Brunner 21 (?); Togo, 0. Kersting 739 (B, destroyed); northern Nigeria: Katagum District, J.M. Dalziel 320 (lectotype K000252777!, designated here; isolectotype $\mathrm{k} 000252778$ !) . = E. rogeri N.E.Br. Fl. Trop. Afr. [Oliver et al.] 6(1.3): 551. 1911. Syntypes: Senegal, Lampsar and Maka, May 1825, Roger s.n. (lectotype K000252776!, designated here); Senegal, 1906, L. Farmar 54 (K000252775!). - E. balsamifera Ait. var. rogeri (N.E. Br.) Maire in Bull. Soc. Hist. Nat. Afr. Nord 29(26): 450. 1938. - E. balsamifera subsp. rogeri (N. E. Br.) Guinea in Anales J. Bot. Madrid 8: 399. 1948. 
Open dendroid shrubs, (0.8)1.5-3(5) m tall, usually dioecious, much branched, erect; upper branches 10-20 cm long, semi-succulent. Rhytidome grayish white to pearly white. Stem leaves (32.2)40.5-77.5(100) x 3.1-7.4 mm, linear; apex obtuse or rounded, mucronate, mucron (0.1)11.5 (2) mm long; subcyathial leaves much shorter and wider than cauline leaves, lanceloate, elliptic or obovateoblong. Cyathia solitary, terminal; involucre broadly conical, 2.5-3.2 x 4.8-7.6 mm; glands 5, yellowish, transversally oblong, $0.1-0.2 \times 0.2-0.4 \mathrm{~mm}$; ovary densely pubescent-sericeous; styles $1.2-1.8 \mathrm{~mm}$, fused $0.2-0.5 \mathrm{~mm}$ from the base, tips bifid, stigmatic lobes 0.2-0-4 mm long. Capsule (5.8)6.4-7.2(7.5) x (6.7)7.4-8.2(8.4) mm, globose, smooth or rugulose, densely pubescent. Seeds ecarunculate, $2.7-4.0 \times 2.5-3.1 \times 2.5-3.2 \mathrm{~mm}$, ovoidsubglobose, rarely ellipsoid or subglobose; hilar zone with an angle of $30-40^{\circ}$.

Distribution and habitat: Euphorbia sepium is distributed in wadis along a southern belt between the Sahara desert and the Sahel region, at elevations between sea level and $500 \mathrm{~m}$ (Table S1, Fig. 1). The species geographic range has likely been expanded by the frequent use of this species for live fencing (Fig. 6P) in the Sahel, expanding its natural range further south into the Sahelian savannas. 
Common names: "yaro" (Senegal, Nigeria, Brown 1911); "waiyaro", "kagua", "kaguwa", "katagum" (Nigeria, Holland $1922)$.

Specimens examined (see Table S1 for additional information): BENIN: A. Chevalier 23620 (P00570817, P00570818); P. Houngnon s.n. (BENIN); J. Krohmer 1985 (FR0018633); Unknown (FR0022735). BURKINA FASO: O. Bognounou 428 (P00570820); R. Martin 282 (FR); B. Toutain 776 (P00570821); B. Toutain 2735 (P00570822). GHANA: G.K. Akpabla 541 (K). MALI: G. Boudet 6643 (P00570823); A. Chevalier 1315 (P00570825, P00570826); A. Chevalier 1316 (P00570827); A. Chevalier 43094 (P00570829); A. Chevalier 43167 (P00570830); A. Chevalier 43180 (P00570824);A. Chevalier 43181 (P00570831); A. Chevalier 43182 (P00570832); J.T. Davey 468 (K); S. de Ganay 148 (P00570834); C. Geerling 2671 (BR16386815, WAG1800090, WAG1800091); F.N. Hepper 3733 (K, P00570828); A. Leclercq 42422 (P00570835); T. Monod 563 (P00570836); M. Wailly 4673 (K, P00570840); M. Wailly 4786 (P00570841); M. Wailly 5148 (P00570842); J. Molero \& al. (BCN43587, BCN43588, BCN45977); J. Raynal \& A. Raynal 5506 (P00570838). MAURITANIA: I. Arvidsson 30 (K); Biologie des Acridiens 23A (P00570814); C. Chatelain CC5259 (G); C. Chatelain CC5260 (G); C. Chatelain CC5261 (G); M. Chudeau s.n. (P00570811, P00570812, P00570813); M. Cludeau (P00570810); J. Coddrington 4 (K); Schmitt 28554 (P00570816); A. 
Marrero s.n. (LPA6573, LPA6574, LPA6723, LPA6724); A. Marrero \& M. González Martín s.n. (LPA6526, LPA6527); T. Monod 3969 (P00570815, P00570837). NIGER: G. Boudet 5335 (P00570843);A. Chevalier 43622 (P00570844);A. Chevalier 43693 (P00570845, WAG1800088); Coen Foundation 13 (K); Coen Foundation 31 (K); P. de Fabrègues 4358 (P05482482); Gaillard-Mission Tilho s.n. (P00570847, P00570848); D.P.M. Guile S.n. (K); J. B. Hall 18083 (K); J. Koechlin 6554 (P00570849); J. Lowe 3700 (K); K. J. Virgo 12 (K). NIGERIA: J.M. Dalziel 320 (K000252777, K000252778); J.M. Dalziel 528 (K); N. Etkin 3 (MO139898); R.W.J. Keay s.n. (K) ; Sampson 8 (K). SENEGAL: J. Audru 2304 (P00570850); J. Audru 3136 (P00570851); E. Bassene S.n. (BCN45976); Brunner 21 (?); O. Caille s.n. (P00570852); O. Caille 25279 (P00570854);A. Chevalier 14610 (P00570853);A. Chevalier 25701 (P00570856); A. Chevalier 25707bis (P00570857); A. Chevalier 34052 (P00570858); L. Farmar 54 (K000252775); F.R. Leprieur s.n. (G); G. Paroisse 43 (P00570859); G.S. Perrottet 128 (P00570860); G.S. Perrottet 741 (G-DC); J. Pujades s.n. (BCN43590); J. Pujades s.n. (BCN43589); J. Raynal \& A. Raynal 5762 (P00570861); G. Roberty s.n. (G, 2 sheets); Roger s.n. (K000252776); R. Schnell s.n. (P00570862); F. Stauffer 908 (DAKAR); F. Stauffer 911 (DAKAR); J. Trochain 1543 (P00570863); J. Trochain 4332 (P00570864); M. Wailly 4598 (P00570865). TOGO: O. Kersting 739 (B, destroyed). WESTERN 
SAHARA: A. Marrero \& J. Caujapé s.n. (LPA32987); R. Riina. \& L. Pokorny 1969 (MA); R. Riina \& L. Pokorny 1970 (MA); Chatelain, C. CC5182 (G) .

\section{Acknowledgements}

We thank the staff of the cited herbaria for allowing us to study their collection, especially C. Chatelain (G), A. Marrero (LPA), H. Rainer (W), F. Stauffer (G), J. Vicens $(B C N), R$. Vogt (B), and M. Hjertson (UPS) for sending us images of herbarium specimens. We thank Irene Navas for help with leaf measurements; Lisa Pokorny for helping with fieldwork; Patricia Barberá, Otavio Marques, and Guilherme Antar for checking specimen data for us in some herbaria. Finally, we are grateful to members of the International Euphorbia Society for providing valuable information on the studied species, especially to Rikus van Veldhuisen, Volker Buddensiek, and Wolfgang Ewest. Authors were supported by grants CGL2015-67849-P (MINECO/FEDER) to IS and CGL2015-73621-JIN (AEI/FEDER) to RR. We appreciate the valuable comments from the editor and two anonymous reviewers, and helpful discussions with Victor steinmann.

\section{References}

Aguirre-Gutiérrez J, Serna-Chavez HM, Villalobos-Arambula AR, Pérez de la Rosa JA, Raes N. 2015. Similar but not equivalent: ecological niche comparison across 
closely-related Mexican white pines. Diversity and distributions 21: 245-257.

Alors D, Lumbsch HT, Divakar PK, Leavitt SD, Crespo A. 2016. An integrative approach for understanding diversity in the Punctelia rudecta species complex (Parmeliaceae, Ascomycota). PloS one 11: p.e0146537. Bally PRO. 1965. Miscellaneous notes on the flora of Tropical East Africa, including descriptions of new taxa. Candollea 20: 13-41

Barres L, Vilatersana R, Molero J, Susanna A, GalbanyCasals M. 2011. Molecular phylogeny of Euphorbia subg. Esula sect. Aphyllis (Euphorbiaceae) inferred from nrDNA and cpDNA markers with biogeografic insights. Taxon 60: 705-720.

Barres L, Galbany-Casals M, Hipp AL, Molero J, Vilatersana R. 2017. Phylogeography and character evolution of Euphorbia sect. Aphyllis subsect. Macaronesicae (Euphorbiaceae). Taxon 66: 324-342.

Broennimann O, Fitzpatrick MC, Pearman PB, Petitpierre B, Pellissier L, Yoccoz NG, Thuiller W, Fortin MJ, Randin C, Zimmermann NE, Graham CH. 2012. Measuring ecological niche overlap from occurrence and spatial environmental data. Global Ecology and Biogeography $21: 481-497$.

Brito D. 2004. Lack of adequate taxonomic knowledge may hinder endemic mammal conservation in the Brazilian 
Atlantic Forest. Biodiversity \& Conservation 13: $2135-2144$

Brown NE. 1911. Euphorbiaceae. In: Thiselton-Dyer WT (Ed.) Flora of Tropical Africa 6 Sect. 1. L. Reeve, Kent, pp. $441-1020$.

Cheek M, Challen G, Lebbie A, Banks H, Barberá P, Riina R. 2016. Discovering Karima (Euphorbiaceae), a new crotonoid genus from West Tropical Africa long hidden within Croton. PloS one 11: p.e0152110.

De Carvalho MR, Bockmann FA, Amorim DS, de Vivo M, de Toledo-Piza M, Menezes NA, de Figueiredo JL, McEachran JD. 2005. Revisiting the taxonomic impediment. Science 307: 353-353.

De Queiroz K. 2007. Species concepts and species delimitation. Systematic Biology 56: 879-886.

Denham SS, Brignone NF, Johnson LA, Pozner RE. 2019. Using integrative taxonomy and multispecies coalescent models for phylogeny reconstruction and species delimitation within the "Nastanthus-Gamocarpha" clade (Calyceraceae). Molecular Phylogenetics and Evolution $130: 211-226$

Di Cola V, Broennimann O, Petitpierre B, Breiner FT, D'amen M, Randin C, Engler R, Pottier J, Pio D, Dubuis A, Pellissier L. 2017. ecospat: an R package to support spatial analyses and modeling of species niches and distributions. Ecography 40: 774-787. 
Dolbeare C. 2016. Designing for behavior change in agroforestry: adoption of live fencing in the African Sahel. A barrier analysis case study from rural Matam, Senegal. Master's thesis. University of Washington

Eke T, Al-Husainy S, Raynor MK. 2000. The spectrum of ocular inflammation caused by Euphorbia plant sap. Archives of Ophthalmology 118: 13-16.

Frajman B, Záveská E, Gamisch A, Moser T, Schönswetter P, STEPPE Consortium, 2019. Integrating phylogenomics, phylogenetics, morphometrics, relative genome size and ecological niche modelling disentangles the diversification of Eurasian Euphorbia seguieriana sl (Euphorbiaceae). Molecular Phylogenetics and Evolution 134: 238-252.

Frajman B, Schönswetter P. 2017. Amphi-Adriatic distributions in plants revisited: Pleistocene transAdriatic dispersal in the Euphorbia barrelieri group (Euphorbiaceae). Botanical Journal of the Linnean Society 185: 240-252.

Giribet G. 2015. Morphology should not be forgotten in the era of genomics-a phylogenetic perspective. Zoologischer Anzeiger 256: 96-103.

Glennon KL, Ritchie ME, Segraves KA. 2014. Evidence for shared broad-scale climatic niches of diploid and polyploid plants. Ecology letters 17: 574-582. 
Govaerts R, Frodin DG, Radcliffe-Smith A. 2000. World Checklist and Bibliography of Euphorbiaceae (and Pandaceae) 1-4: 1-1622. The Board of Trustees of the Royal Botanic Gardens, Kew.

Guisan A, Petitpierre B, Broennimann O, Daehler C, Kueffer C. 2014. Unifying niche shift studies: insights from biological invasions. Trends in Ecology \& Evolution 29: 260-269.

Hearn DJ, Poulsen T, Spicer R. 2013. The evolution of growth forms with expanded root and shoot parenchymatous storage is correlated across the eudicots. International Journal of Plant Sciences 174: 1049-1061.

Hijmans RJ, Phillips S, Leathwick J, Elith J. 2013. dismo: Species distribution modeling. R package version $0.8-$ 17.

Hijmans RJ, Cameron SE, Parra JL, Jones PG, Jarvis A. 2005. Very high resolution interpolated climate surfaces for global land areas. International Journal of Climatology: A Journal of the Royal Meteorological Society 25: 1965-1978.

Holland JH. 1922. The useful plants of Nigeria, part. 4. Kew Bulletin of Miscellaneous Information, Additional Series IX: 537-963. 
Horn JW, Xi Z, Riina R, Peirson JA, Yang Y, Dorsey BL, Berry PE, Davis CC, Wurdack K. 2014. Evolutionary bursts in Euphorbia (Euphorbiaceae) are linked with photosynthetic pathway. Evolution 68: 3485-3504.

Hubert N, Hanner R. 2015. DNA barcoding, species delineation and taxonomy: a historical perspective. DNA barcodes 3: 44-58.

Jiménez-Mejías P, Hahn M, Lueders K, Starr JR, Brown BH, Chouinard BN, Chung KS, Escudero M, Ford BA, Ford KA, Gebauer S. 2016. Megaphylogenetic specimen-level approaches to the Carex (Cyperaceae) phylogeny using ITS, ETS, and matK sequences: implications for classification the global Carex group. Systematic Botany 41: 500-518.

Lavinia PD, Bustos EON, Kopuchian C, Lijtmaer DA, García NC, Hebert PD, Tubaro PL. 2017. Barcoding the butterflies of southern South America: Species delimitation efficacy, cryptic diversity and geographic patterns of divergence. PloS one 12: p.e0186845.

LPWG (Legume Phylogeny Working Group). 2013. Legume phylogeny and classification in the 21st century: progress, prospects and lessons for other speciesrich clades. Taxon 62: 217-248.

Li YC, Wen J, Ren Y, Zhang JQ. 2019. From seven to three: Integrative species delimitation supports major 
reduction in species number in Rhodiola section Trifida (Crassulaceae) on the Qinghai-Tibetan Plateau. Taxon 68: 268-279.

Lücking R. 2019. Stop the abuse of time! Strict temporal banding is not the future of rank-based classifications in Fungi (including Lichens) and other organisms. Critical Reviews in Plant Sciences 38: $199-253$.

Mairal M, Sanmartín I, Pellissier L. 2017. Lineagespecific climatic niche drives the tempo of vicariance in the Rand Flora. Journal of Biogeography $44: 911-923$.

Maire H. 1938. Contributions à l'étude de la flore de l'Afrique du Nord 26. Bulletin de la Société d'histoire naturelle de l'Afrique du nord 29: 451. Marrero MC, Rodríguez O, Wildpret W. 1999. Contribución al estudio taxonómico y descriptivo de la tabaiba dulce (Euphorbia balsamifera). Revista de la Academia Canaria de Ciencias 10(3-4): 265-286.

Miller AG, Morris, M. 2004. Ethnoflora of the Sogotra Archipelago. Royal Botanic Garden Edinburgh. Molero J, Gartnatje T, Rovira A, Garcia-Jacas N, Susanna A. 2002. Karyological evolution and molecular phylogeny in Macaronesian dendroid spurges (Euphorbia subsect. Pachycladae). Plant Systematics and Evolution 231: 109-132. 
Naciri Y, Linder HP. 2015. Species delimitation and relationships: the dance of the seven veils. Taxon $64: 3-16$

Nugnes F, Bernardo U, Viggiani G. 2017. An integrative approach to species discrimination in the Anagrus atomus group sensu stricto (Hymenoptera: Mymaridae), with a description of a new species. Systematics and Biodiversity 15: 582-599.

Olmstead RG, Bedoya AM. 2019. Whole genomes: the holy grail. A commentary on: Molecular phylogenomics of the tribe Shoreeae (Dipterocarpaceae) using whole plastidgenomes. Zoology 22: 240-249.

Olmstead RG, Zjhra ML, Lohmann LG, Grose SO, Eckert AJ. 2009. A molecular phylogeny and classification of Bignoniaceae. American Journal of Botany 96: 17311743.

Otang WM, Grierson DS, Afolayan AJ. 2014. A survey of plants responsible for causing irritant contact dermatitis in the Amathole district, Eastern Cape, South Africa. Journal of ethnopharmacology 157: 274284.

Peirson JA, Bruyns PV, Riina R, Morawetz JJ, Berry PE. 2013. A molecular phylogeny and classification of the largely succulent and mainly African Euphorbia subg. Athymalus (Euphorbiaceae). Taxon 62: 1178-1199. 
Perez J, Roca-Salinas A. 1977. Palinologia del género Euphorbia L. en la Macaronesia. Botánica Macaronésica 4: 77-91.

Perkins AJ. 2019. Molecular phylogenetics and species delimitation in annual species of Hydrocotyle (Araliaceae) from South Western Australia. Molecular Phylogenetics and Evolution 134: 129-141.

Petitpierre B, Kueffer C, Broennimann O, Randin C, Daehler C, Guisan A. 2012. Climatic niche shifts are rare among terrestrial plant invaders. Science 335: 13441348 .

Pokorny L, Riina R, Mairal M, Meseguer AS, Culshaw V, Cendoya J, Serrano M, Carbajal R, Ortiz S, Heuertz M, Sanmartín I. 2015. Living on the edge: timing of Rand Flora disjunctions congruent with ongoing aridification in Africa. Frontiers in Genetics 6: 154.

Prata EM, Sass C, Rodrigues DP, Domingos FM, Specht CD, Damasco G, Ribas CC, Fine PV, Vicentini A. Towards integrative taxonomy in Neotropical botany: disentangling the Pagamea guianensis species complex (Rubiaceae) . Botanical Journal of the Linnean Society $188: 213-231$

R Core Team. 2017. R: A language and environment for statistical computing computer program, version by $R$ Core Team. Vienna, Austria. 
Rannala B. 2015. The art and science of species delimitation. Current Zoology 61: 846-853.

Riina R, Peirson JA, Geltman DV, Molero J, Frajman B, Pahlevani A, Barres L, Morawetz JJ, Salmaki Y, Zarre S, Kryukov A., 2013. A worldwide molecular phylogeny and classification of the leafy spurges, Euphorbia subgenus Esula (Euphorbiaceae). Taxon 62: 316-342.

Sanmartín I, Anderson CL, Alarcon M, Ronquist F, Aldasoro JJ. 2010. Bayesian island biogeography in a continental setting: the Rand Flora case. Biology letters 6: 703-707.

Sattler T, Bontadina F, Hirzel AH, Arlettaz R. 2007. Ecological niche modelling of two cryptic bat species calls for a reassessment of their conservation status. Journal of Applied ECology 44: 1188-1199.

Senut B, Pickford M, Ségalen L. 2009. Neogene desertification of Africa. Comptes Rendus Geoscience $341: 591-602$.

Sexton JP, Hangartner SB, Hoffmann AA. 2014. Genetic isolation by environment or distance: which pattern of gene flow is most common? Evolution 68: 1-15. Smith MA, Wood DM, Janzen DH, Hallwachs W, Hebert PD. 2007. DNA barcodes affirm that 16 species of apparently generalist tropical parasitoid flies (Diptera, Tachinidae) are not all generalists. 
Proceedings of the National Academy of Sciences 104: $4967-4972$

Solís-Lemus C, Knowles LL, Ané C. 2015. Bayesian species delimitation combining multiple genes and traits in a unified framework. Evolution 69: 492-507.

Soreng RJ, Peterson PM, Romaschenko K, Davidse G, Teisher JK, Clark LG, Barberá, P, Gillespie LJ, Zuloaga FO. 2017. A worldwide phylogenetic classification of the Poaceae (Gramineae) II: An update and a comparison of two 2015 classifications. Journal of Systematics and Evolution 55: 259-290.

Sousa JO, Suz LM, García MA, Alfredo DS, Conrado LM, Marinho P, Ainsworth AM, Baseia IG, Martín MP. 2017. More than one fungus in the pepper pot: Integrative taxonomy unmasks hidden species within Myriostoma coliforme (Geastraceae, Basidiomycota). PloS one 12: p.e0177873.

Sukumaran J, Knowles LL. 2017. Multispecies coalescent delimits structure, not species. Proceedings of the National Academy of Sciences 114: 1607-1612.

Turland NJ, Wiersema JH, Barrie FR, Greuter W, Hawksworth DL, Herendeen PS, Knapp S, Kusber WH, Li DZ, Marhold K, May TW. 2018. International Code of Nomenclature for algae, fungi, and plants (Shenzhen Code) adopted by the Nineteenth International Botanical Congress Shenzhen, China, July 2017. 
Van Ee BW, Riina R, Berry PE. 2011. A revised infrageneric classification and molecular phylogeny of New World Croton (Euphorbiaceae). Taxon 60: 791-823.

Vasas A, Rédei D, Csupor D, Molnár J, Hohmann J. 2012.

Diterpenes from European Euphorbia species serving as prototypes for natural product-based drug discovery. European journal of organic chemistry 2012: 51155130 .

Villaverde T, Pokorny L, Olsson S, Rincón M, Johnson M, Gardner EM, Wickett NJ, Molero J, Riina R, Sanmartín

I. 2018. Bridging the micro and macroevolutionary levels in phylogenomics: Hyb-Seq solves relationships from populations to species and above. New Phytologist 220: 636-650.

Warren DL, Glor RE, Turelli M. 2008. Environmental niche equivalency versus conservatism: quantitative approaches to niche evolution. Evolution 62: 28682883.

Webster GL. 1986. Irritant plants in the spurge family (Euphorbiaceae). Clinics in dermatology 4: 36-45. Xiao W, Simpson BB. 2017. A new infrageneric classification of Meconopsis (Papaveraceae) based on a well-supported molecular phylogeny. Systematic Botany 42: 226-233.

Yang L, Kong H, Huang JP, Kang M. 2019. Different species or genetically divergent populations? Integrative 


\author{
species delimitation of the Primulina hochiensis \\ complex from isolated karst habitats. Molecular \\ Phylogenetics and Evolution 132: 219-231. \\ Zachos JC, Dickens GR, Zeebe RE. 2008. An early Cenozoic \\ perspective on greenhouse warming and carbon-cycle \\ dynamics. Nature 451: 279.
}


Table 1 Values of niche overlap (Schöner's D) obtained for each species pair-wise comparison of the studied Euphorbia taxa. Schöner's D varies between 0 (no niche overlap) and 1 (complete niche overlap)

\begin{tabular}{lccc}
\hline & $\begin{array}{l}\text { E. } \\
\text { adenensis }\end{array}$ & $\begin{array}{l}\text { b. } \\
\text { balsamifera }\end{array}$ & E. sepium \\
E. adenensis & 1 & 0.271 & 0.071 \\
$\begin{array}{l}\text { E. } \\
\text { balsamifera }\end{array}$ & 0.271 & 1 & 0.004 \\
E. Sepium & 0.071 & 0.004 & 1 \\
\hline
\end{tabular}


Table 2 Results of the niche equivalency and similarity tests shown as P-values per each species pairwise comparison. The null hypothesis is that two given niches are not more ("greater") or less ("lower") equivalent or similar than expected by chance (random niches). Significant P-values $(<0.05)$ are in bold

\begin{tabular}{|c|c|c|c|c|c|c|}
\hline & \multicolumn{6}{|c|}{ Equivalency } \\
\hline & Greater & Lower & Greater & Lower & Greater & Lower \\
\hline & \multicolumn{2}{|c|}{ E. adenensis } & \multicolumn{2}{|c|}{ E. balsamifera } & \multicolumn{2}{|c|}{ E. sepium } \\
\hline E. adenensis & - & & 0.386 & 0.624 & 0.148 & 0.841 \\
\hline$E$. & & & & & & \\
\hline balsamifera & 0.366 & 0.554 & & - & 1 & 0.009 \\
\hline \multirow[t]{3}{*}{ E. sepium } & 0.139 & 0.832 & 1 & 0.009 & - & - \\
\hline & Greater & Lower & Greater & Lower & Greater & Lower \\
\hline & \multicolumn{2}{|c|}{ E. adenensis } & \multicolumn{2}{|c|}{ E. balsamifera } & \multicolumn{2}{|c|}{ E. sepium } \\
\hline E. adenensis & - & - & 0.019 & 0.99 & 0.445 & 0.624 \\
\hline \multicolumn{7}{|l|}{$E$. } \\
\hline balsamifera & 0.029 & 1 & - & - & 0.544 & 0.653 \\
\hline E. sepium & 0.624 & 0.346 & 0.723 & 0.366 & - & - \\
\hline
\end{tabular}


Table 3 Values of niche expansion $(\varepsilon)$, niche stability $(\sigma)$, and niche unfilling ( $u$ ) for the species' niche pairwise comparisons (see Fig. 4)

\begin{tabular}{|c|c|c|c|c|c|c|c|c|c|}
\hline & \multicolumn{3}{|c|}{ E. adenensis } & \multicolumn{3}{|c|}{ E. balsamifera } & \multicolumn{3}{|c|}{ E. sepium } \\
\hline & $\varepsilon$ & $\sigma$ & $v$ & $\varepsilon$ & $\sigma$ & $v$ & $\varepsilon$ & $\sigma$ & $v$ \\
\hline$E$. & & & & 0.0 & 0.9 & 0.1 & 0.5 & 0.4 & 0.2 \\
\hline adenensis & - & - & - & 01 & 99 & 21 & 52 & 47 & 64 \\
\hline \multicolumn{10}{|l|}{$E$. } \\
\hline balsamifer & 0.1 & 0.8 & 0.0 & & & & 0.4 & 0.5 & 0.6 \\
\hline \multirow[t]{2}{*}{$a$} & 21 & 79 & 01 & - & - & - & 65 & 35 & 37 \\
\hline & 0.2 & 0.7 & 0.5 & 0.6 & 0.3 & 0.4 & & & \\
\hline E. sepium & 65 & 35 & 52 & 37 & 63 & 65 & - & - & - \\
\hline
\end{tabular}


Table 4 Univariate (ANOVA) and multivariate (MANOVA) analysis of variance conducted on leaf size measurements of Euphorbia specimens $(n=80)$ from three species ( $E$. adenensis, E. balsamifera, and $E$. sepium)

\begin{tabular}{lcc}
\multicolumn{1}{c}{ Leaf measurement } & F-test & Significance \\
\hline Maximum length (A) & 106.20 & $\mathrm{~S}$ \\
Maximum width (B) & 2.322 & $\mathrm{NS}$ \\
Length from base to maximum width & (C) & 70.81 \\
Mucron length (D) & 35.42 & $\mathrm{~S}$ \\
MANOVA (A-D) & 15.207 & $\mathrm{~S}$ \\
Ratio A/B (F) & 133.9 & $\mathrm{~S}$ \\
\end{tabular}

Letters A-D correspond to the box plots in Fig. 5; $\mathrm{S}=$ significant ( $\mathrm{p}$ $<0.001) ; \mathrm{NS}=$ not significant 


\section{Figure Legends}

Fig. 1. Map showing georeferenced collections of the three species proposed in this study: Euphorbia adenensis

(diamonds), E. balsamifera s.s. (circles), and E. sepium (triangles). The two shaded areas reflect the former taxonomic circumscription recognizing a single species ( $E$. balsamifera s.l.) with two subspecies (subsp. balsamifera on the west and subsp. adenensis on the east).

Fig. 2. Maximum clade credibility (MCC) tree of Euphorbia subgenus Athymalus based on 296 exons of the nuclear genome (Villaverde et al., 2018). The arrow indicates section Balsamis which includes the three well supported clades corresponding to E. adenensis (19 accessions), E. balsamifera (81 accessions), and E. sepium (10 accessions). Bayesian estimates of divergence times are given at each node above branches; clade support (Posterior Probabilities, PP) is 1 for all nodes in the tree except for the node leading to E. noxia (dashed line, $0.82 \mathrm{PP})$. Node bars represent the 95\% highest posterior density intervals of the divergence time estimates using a strict clock analysis. Figure modified from Villaverde et al., (2018, Fig. 4a). 
Fig. 3. Comparison of climatic niches among the three species of Euphorbia recognized here: E. adenensis, E. balsamifera, and E. sepium. Cells along the diagonal from upper left to bottom right show the niche occupied by each species, the other cells represent composed niche overlap of species pairs. Colors indicate niche expansion (green), niche stability (blue), and niche unfilling (red). Solid lines enclose all available environments for each range; dashed lines represent 90 th percentile of the background environment for the paired species ranges.

Fig. 4. PCA scatterplot, including within-group centroid, of the first two principal components based on 19 bioclimatic variables associated to occurrence points of the thtree proposed Euphorbia species: orange circle (E. adenensis), blue triangle (E. balsamifera), green square (E. sepium).

Fig. 5. Box-whisker plots and Principal Component Analysis (PCA) of leaf size measurements of Euphorbia specimens (n = 80) from E. adenensis (yellow), E. balsamifera (blue), and E. sepium (green). Each box represents the interquartile range, which contains $50 \%$ of the values and the median (horizontal line across the box); the whiskers are the lines that extend from the box to the highest and lowest values, excluding outliers (o). A, Leaf length, 
including a silhouette of the average leaf shape and size for each species. B, Leaf maximum width. C, Length from leaf base to the point of maximum width. D, Mucron length. E, Ratio between leaf length (A) and leaf maximum width (B). F, Scatter plot of the first two components of the PCA based on the five leaf measurements. Row data are provided in Supporting Information (Table S3).

Fig. 6. Representative field images of the three species: Euphorbia adenensis: A, Plant growing in stony desert, Oman. B, Male cyathium. C, Female cyathium. D, Habitat, Oman. E, Young female cyathium. F, Mature capsule. Euphorbia balsamifera: G, Population on volcanic rocks, El Hierro Island (Canaries). H, Male cyathium. I, Female cyathium. J, Plant in sandy substrate, coast of NW Africa. K, Developing ovary. L, Mature capsule. Euphorbia sepium: M, Population in a desert wadi, Western Sahara. $\mathbf{N}$, Male cyathium. O, Female cyathium. P, Live fence, NE Senegal. Q, Detail of the long narrow leaves. Photos: Flickr public domain (A, B, C.), C. Dolbeare (P), C. Lemmel (M, N, Q), D. Marquina Reyes (K), J. Mesa (L), J.J. Morawetz (D, E, F), J.P. Peltier, www.teline.fr (H, I, J), R. Riina (O, R), T. Villaverde (G) . 


\section{Supporting Information}

Table S1. List of plant specimens examined for the taxonomic treatment, climatic niche analysis, and distribution map (Fig. 1). Some records were filtered and curated from an original row-set of data downloaded from GBIF (http://doi.org/10.15468/dl.0qiyuu) others come from other sources (i.e., herbarium collections not available in GBIF). We include collector name, collection number, herbarium code, locality information from herbarium specimen labels, and estimated geographic coordinates for de novo georeferenced specimens.

Table s2. Descriptor loadings of the first two principal components (PC1, PC2) of the PCA of 19 bioclimatic variables (see Fig. 4).

Table s3. Leaf measurements used for the morphometric analysis (see Table 4, Fig. 5) on 80 selected specimens of Euphorbia adenensis, E. balsamifera, and E. sepium. 


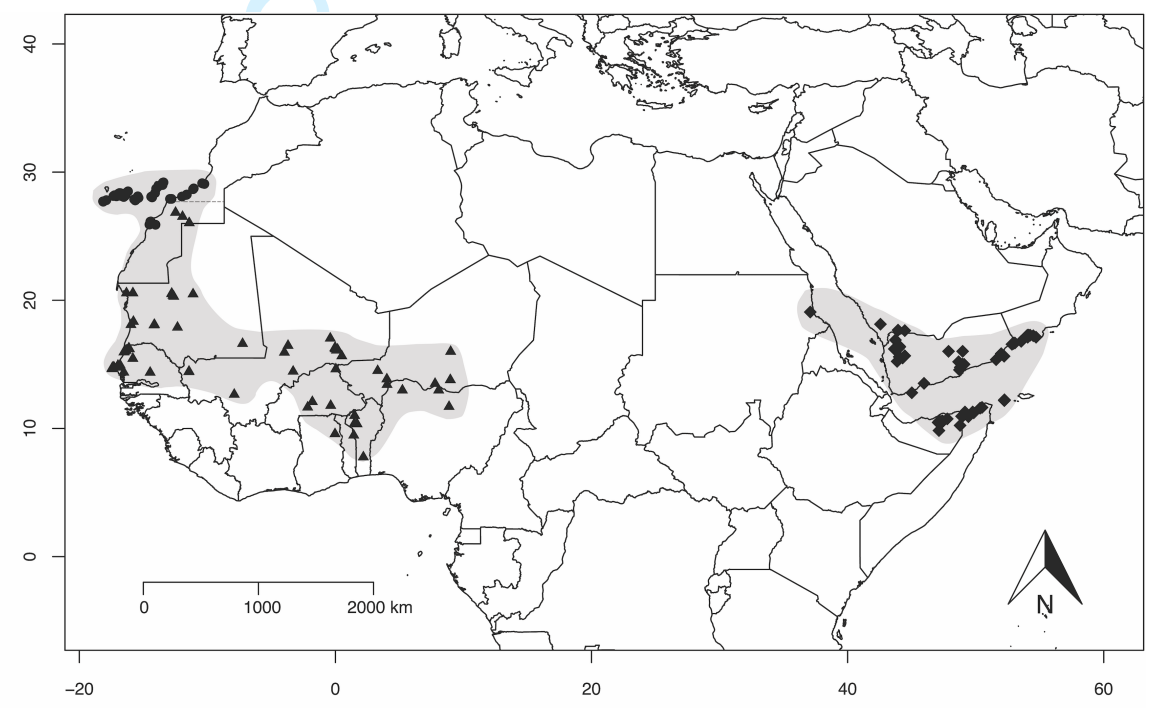

41 
E. antso

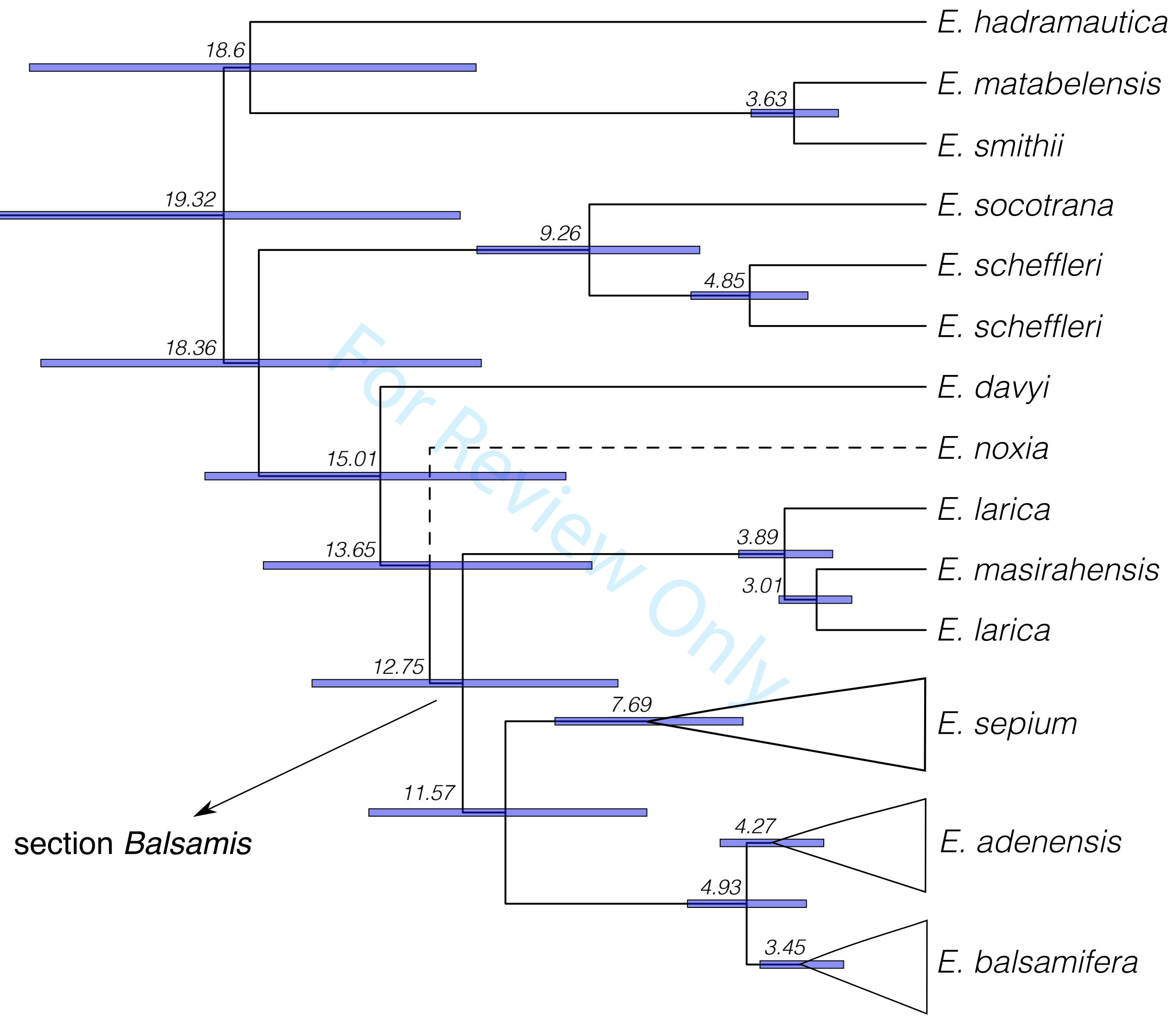



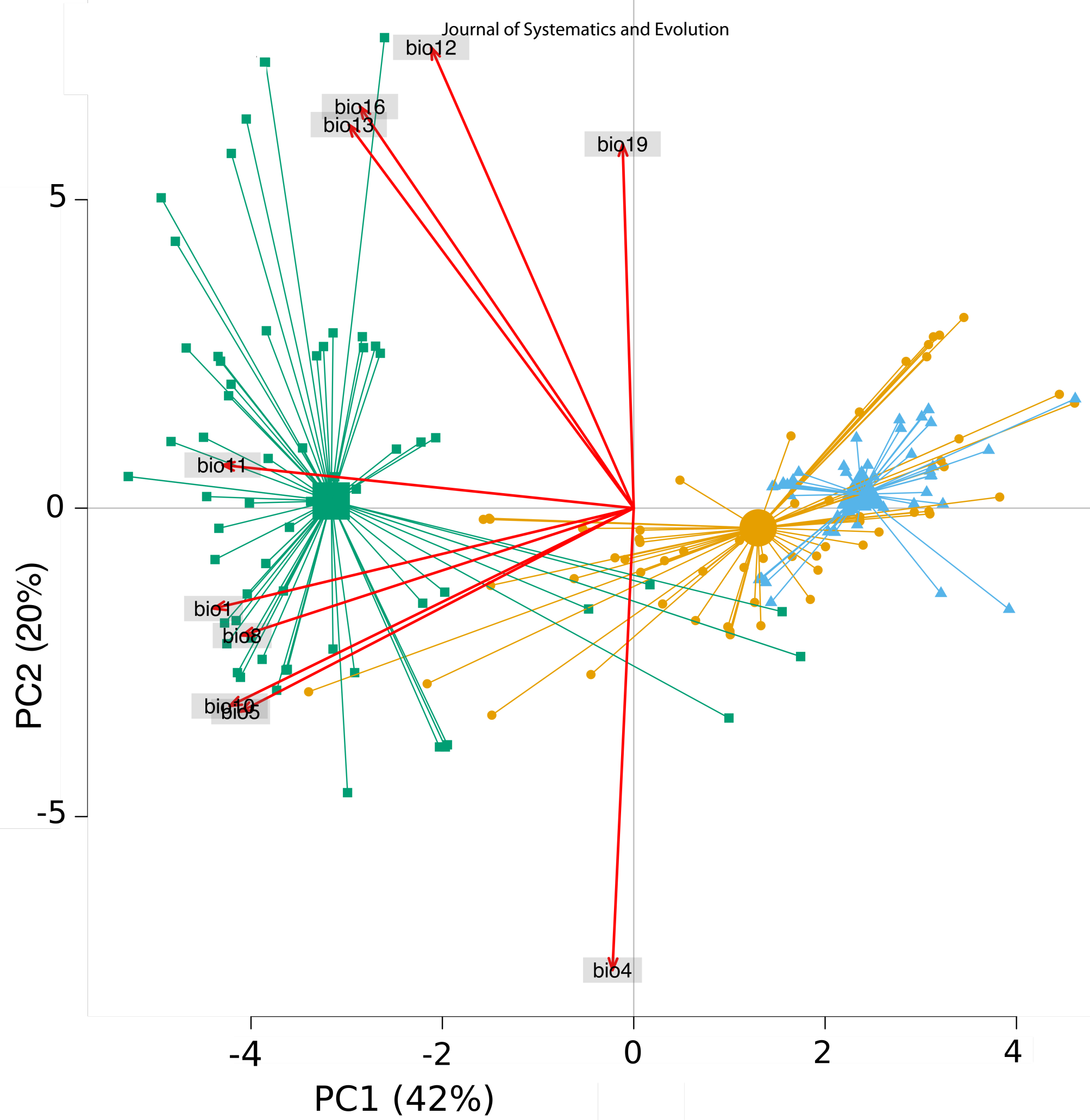


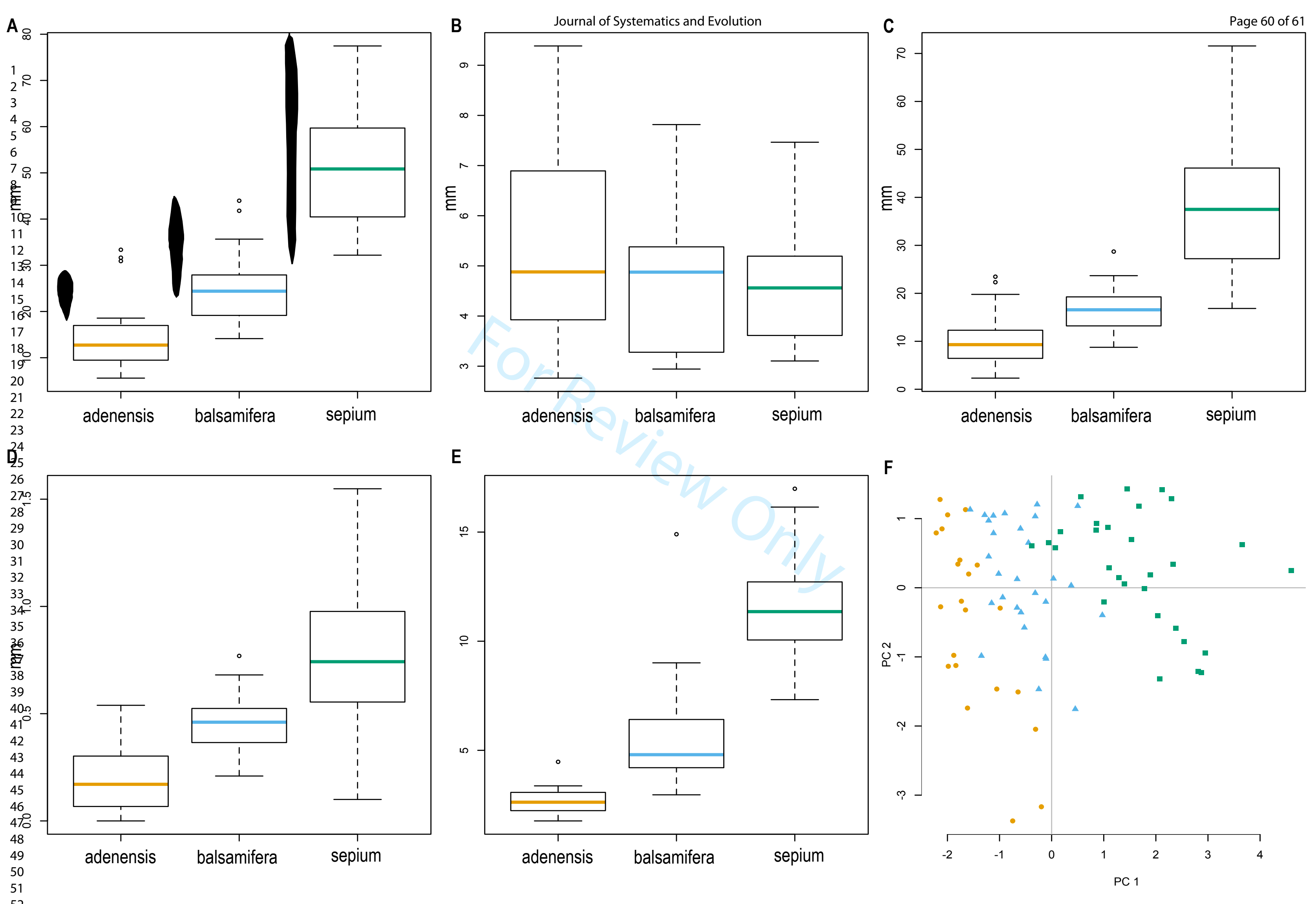


Fig. 6. Representative field images of the three species: Euphorbia adenensis: A, Plant growing in stony desert, Oman. B, Male cyathium. C, Female cyathium. D, Habitat, Oman. E, Young female cyathium. F, Mature capsule. Euphorbia balsamifera: G, Population on volcanic rocks, El Hierro Island (Canaries). $\mathrm{H}$, Male cyathium. I, Female cyathium. J, Plant in sandy substrate, coast of NW Africa. K, Developing ovary. L, Mature capsule. Euphorbia sepium: M, Population in a desert wadi, Western Sahara. N, Male cyathium. O, Female cyathium. P, Live fence, NE Senegal. Q, Detail of the long narrow leaves. Photos: Flickr public domain (A, B, C.), C. Dolbeare (P), C. Lemmel (M, N, Q), D. Marquina Reyes (K), J. Mesa (L), J.J. Morawetz $(D, E, F)$, J.P. Peltier, www.teline.fr $(H, I, J)$, R. Riina $(O, R)$, T. Villaverde $(G)$. 